\title{
戦前の関東圏における別荘の立地とその類型に関する研究 A STUDY ON THE DEVELOPMENT AND TYPES OF VILLAS IN JAPAN (1860'-1940')
}

\author{
十代田 朗*, 渡辺 貴介**, 安島博 幸*** \\ Akira SOSHIRODA, Takasuke WATANABE and Hiroyuki YASUJIMA
}

\begin{abstract}
This study tries to explain the development and types of villas in Japan $\left(1860^{\prime}-1940^{\prime}\right)$ for the period as the influence of the Western society.

For this purpose, historical records on each resort area, owner of villas, locations and plans of villas are analyzed.

This study revealed 1) the evolutional process of villas in the Kanto region, 2) the factors which caused such development, and 3) the grouping of villa types in Japan (1860'-1940') on the base of the locations and the purposes of possession.
\end{abstract}

Keywords : villa, location, life style, concept 別荘, 立地, 生活様式, コンセプト

\section{1. 研究の背景と目的}

近年, 余㑡時間の增大，内需拡大の要請，地域振興熱 の高まりを背景に, 官民挙げてリゾートの整備構想が全 国各地で揭げられており，一大ブームとなっている。そ の反面，環境破壊，画一的な開発なゼ各種の問題点も指 摘され始めている。それらの開発プランの大部分は欧米 の先進事例を範としているが，気候風土，国民性が異な るわが国でのリゾートのあり方を考えるうえでは，西洋 社会の影響を受けてリゾートがわが国に誕生したリゾー 卜の黎明期に立ち返ってみることも必要であろう。そこ で，その時代なりの豊かな階層の人々が希求したりゾー 卜像をたどってみることによって，わが国のリゾートの 原型のひとつを抽出することを試みた。

戦前のリゾートに関する研究としては，湘南，軽井沢 といったあるひとつのリゾートに着目してその成立と展 開の過程を論じた筆者らのグループによる一連の研究が ある蚆。しかし，これらは各リゾート間の影響関係や 共通する背景を含めて論じてはおらず，戦前におけるわ が国のリゾートに関する全域的な変遥の様子やその社 会・風俗的背景について全体像を描くには至っていな い。

また，戦前のリゾートの中心的構成要素であった別荘
に関しては，近代建築史的な視点から論じた宍戸 實， 藤森照信, 河東義之らのグループによる一連の研究があ るせ21。これらは別荘建築の樣式に関しては貴重な知見 を得る研究であるが, 地形, 気候, 交通, 都市環境といっ た外的条件との関係，別荘という特殊な用途に注目した 使い方に関する検討を行ってはいない。

そこで, 本研究では,

(1) 明治期から戦前までの関東圏において，別荘地はぼ の上うな場所に成立し，展開したか。また，そのきっか けはどんなことであったか。

(ここでいう別荘地とは,「ある程度の戸数の別荘が集 積していた地域」とする。)

(2) 別荘を所有するにあたって，どのような社会・風俗 的背景が存在したか。

(3) それらを受けて,どのようなタイプの別荘が存在し， 立地，使い方などにどのような特徵を持っていたか。 の以上の 3 点を明らかにすることを研究の目的とする。

\section{2. 研究の構成と方法}

まず，関東圈全域に関する地方史・地誌などの新旧の 文献を収集・分析することにより，明治期から戦前まで 関東圏における別荘地の成立とその後の展開 (3 章),

\footnotetext{
* 東京工業大学社会工学科 助手·工修

** 東京工業大学社会工学科 教授 $\cdot$ 工博 Dr. Eng.

Prof., Dept. of Architecture Kanazawa Institute of Technology, Dr. Eng. 
と成立のきっかけを明らかにする (4 章)。次に，それ らから抽出した別荘地の成立 ・展開の社会・風俗的背景 を, 当時の世相を記した新聞記事, 風俗・医学関連の新 旧の文献を収集・分析することにより考察する (5 章)。

それらをふまえて, 立地, 社会・風俗的背景の 2 つか ら別荘のタイプ分類を行い，さらに，(1)現地踏査，ヒア リング, 新旧の地図, (2)別荘所有者の伝記・日記・自伝 などを収集・分析することにより，その使い方など各夕 イプの特徵を明らかにする（6 章)。

\section{3. 明治期から戦前までの関東圈における別荘地の成立 とその後の展開}

明治初めから戦前までの間, 関東圈の中で, 別荘地が いつ，どのような場所に成立し展開していったのかを時 代を追って考察する。

明治維新から明治 20 年頃までは, 江戸期の延長で東 京に下屋敷跡を中心として別邸が構えられただけであっ た。これは, 関東圈全域に鉄道網が整備される以前の時 代なので，時間あたりに到達できる距離が基本的には江 戸期と変わらず，まだ非常に短かったことがひとつの要 因と考えられる。

明治 20 年頃になると, 同 20 年の東海道線の関通を始 め急速に鉄道網が発達し, 地方への到達性が飛躍的に向 上したため, 外国人，政府高官らの避暑䫝望，ステイタ スシンボルへの欲求が表面化した。鉄道網に沿って，日 光・箱根・江ノ島といった既存観光地とその周辺に次々 と別荘地が成立した。この時代の主流は海浜部であり, 明治 45 年に湘南では鎌倉だけでも 400 戸の別荘が立地 していたが刘，それに対して，高原部では最も多かっ た軽井沢でさえも 200 戸弱（193戸）であった文)。

第一次大戦後になると新たな別荘地の成立がみられ
る。新たな鉄道の延伸に沿って,電化など列車の性能アッ プによる到達時間の短縮もあって, 高原部を中心に遠隔 地に広がっていった。戦後, 好況になって新しい富裕層 が生まれたという需要サイドの条件と, 箱根, 軽井沢を 中心に堤康次郎らによる開発分譲方式によって別荘が大 量供給されたという供給サイドの条件によって別荘所有 者の階層も広がっていった。この様子は各地の別荘所有 者名簿などにみることができる塱3。軽井沢の別荘数は 昭和 5 年に 819 戸になっており侪，明治 45 年に比して 4 倍以上と急速に増加している。

このような箱根, 軽井沢といった代表的な高原別荘地

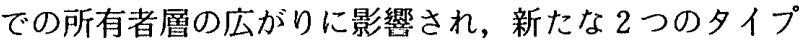
の別荘地が生まれた。

ひとつは俗化した軽井沢を嫌った軽井沢の別荘所有者 によって作られた別荘地で，宣教師による野尻湖「国際 村」文31，学者による北軽井沢「法政大学村」文4)がある。 もうひとつは，軽井沢の繁栄に做った別荘地で，俱楽部

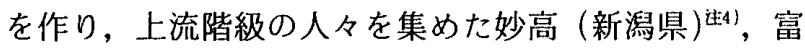

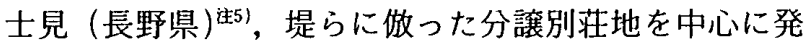
展していった山中湖（山梨県），那須（杤木県）がある。 以上の考察から, 別荘地の分布は, 明治 20 年頃と第 一次大戦を境に 2 回大きく広がったといえる。そこで, 明治維新から明治 20 年比までの都市近郊にしか別荘地 がみられない時代を第 I 期, 図一1 の左側のような地域 で別荘地の成立がみられる 20 年頃から第一次大戦まで 時代を第 II 期，その後，大戦後の図一1 の右側のように 新たな別荘地が成立する時代を第四期として，この時代 区分により以下の論を展開していく。

\section{4. 各別荘地成立のきっかけ}

各別荘地に関する文献を考察することによって，別荘
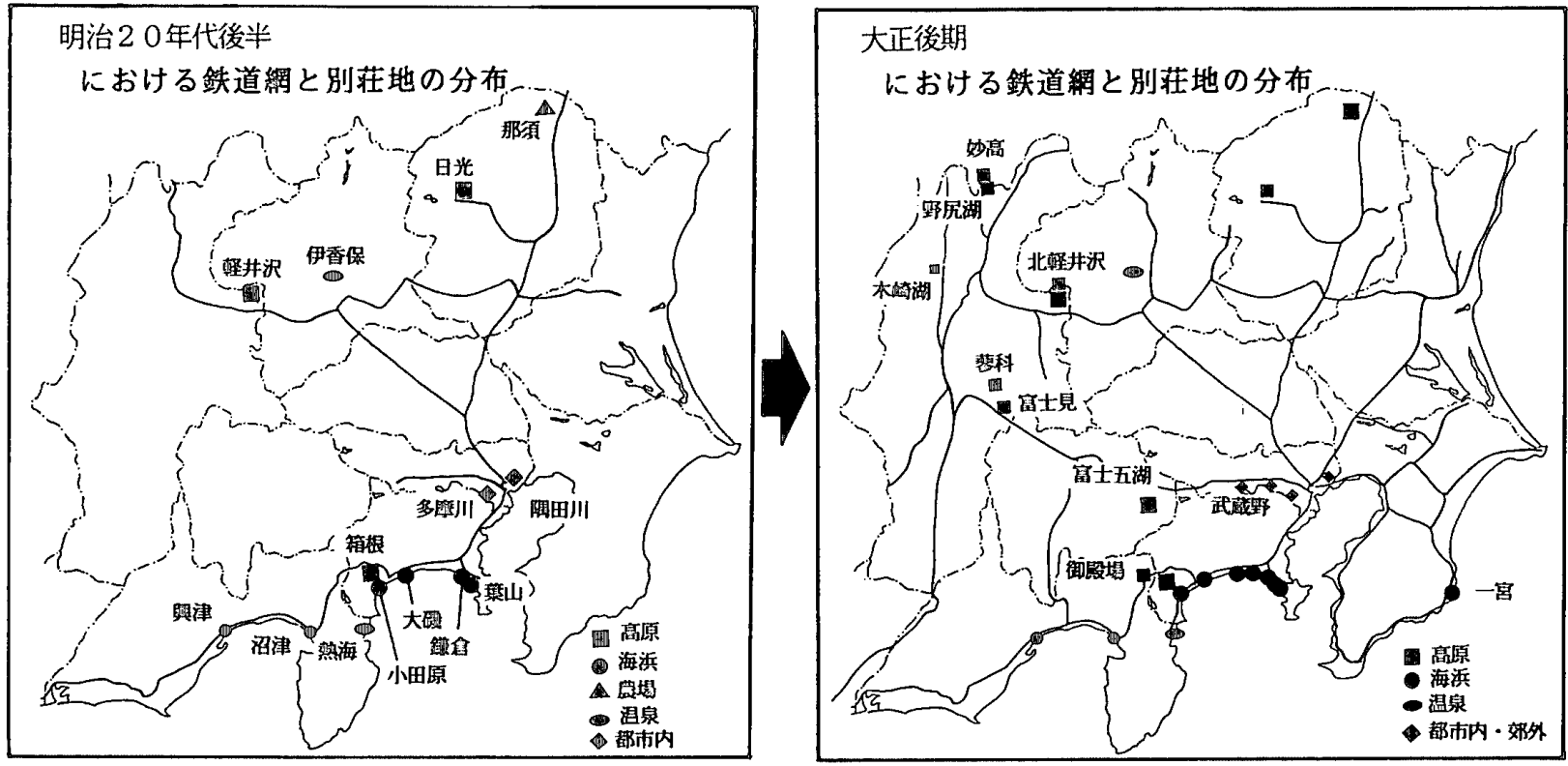

図一1 明治 20 年代後半と大正後期における鉄道網と別荘地の分布 


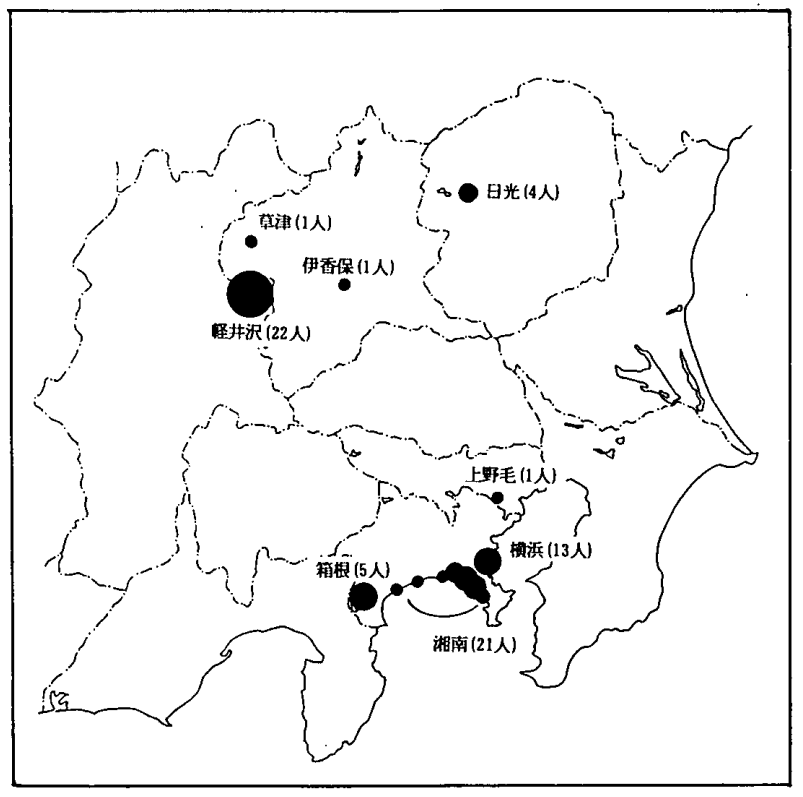

図一2 明治 25 年における外国人別荘の分布 (文献 5) 上り作成)

地が成立していくきっかけとして重要な役割を果たす事 柄として，(1)外国人による別荘構築，(2)皇族による別荘 構築，(3)リゾートホテルの開業，の3つが抽出された。 (1) 外国人による別荘構築

明治 25 年の外務省記録によると站，明治 32 年の内 地雑居制の実施以前は，外国人は土地家屋の所有を認め られていなかったが，彼らは日本人の名義を借りて別荘 を所有していた。外国人所有の別荘は，軽井沢の 22 户 を筆頭に，箱根，日光，湘南なよ゙，その後別荘地として 発展していった地に多く存在していることがわかる（図 -2)。外国人は仲間に周辺での別荘所有を萀め次第に集 まって独自の別荘集落を形成していった。当時，外国人 による観光目的の旅行は 'NUMBERED ROUTES' と 呼ばれる 20 の決まったルートしか許可されていなかっ たため吝，そのルート上にある箱根，日光，軽井沢な どが選ばれている。また，各居留地から十里までは外出 が許可されていたため横浜居留地から十里内にある湘南 には多くの別荘が構えられた文》。内地雑居制実施以後 では, 御殿場, 野尻湖がこの成立タイプの別荘地であ

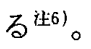

\section{(2) 皇族による別荘構築}

東京以外の地域の御用邸は, 明治 30 年の時点で, 日光, 伊香保, 箱根, 葉山, 熱海, 沼津に構えられていたが（図

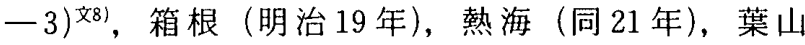
(同 27 年) なよ゙での離宮，御用邸の建設は，政府高官 など特権階級の人々の周辺への別荘構築を促進し，それ らの地がわが国の代表的な別荘地として発展する最初の きっかけとなった。これらの御用邸の多くの適地選定に は宮内省御用掛の医師であったドイッ人・E、ベルツが 深くかかわっており，病弱だった皇太子 (大正天皇) の 転地療養が主なる目的で西洋医学が導入されたものであ

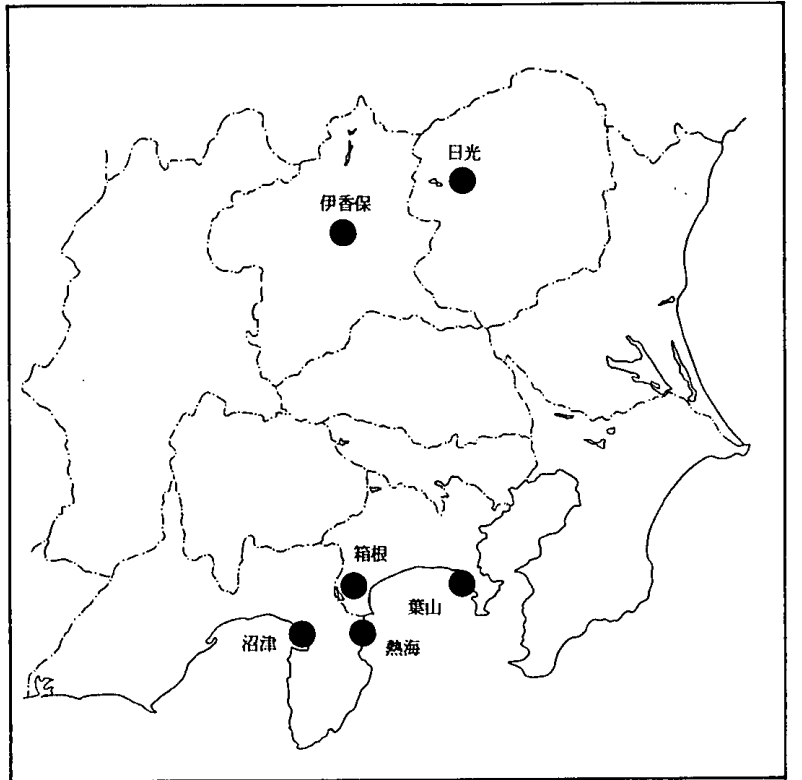

図一3 明治 30 年における御用邸の分析（文献 8）より作成）

る（5-(3)詳述）。また, 大正末期に建てられた富士五湖 の梨本宮, 妙高の久雨宮などの宮家の別邸構築齐81も第 III期での新たな別荘地成立のきっかけとして大きく寄与 したことがその地の地方史関連の文献から推察される。

(3) リゾートホテルの開業

リゾートホテルは, 日光の金谷ホテル (明治 6 年), 箱根の富士屋ホテル (同 11 年), 軽井沢の万平ホテル (同 27 年) など明治初めから外国人がしばしば訪れて いた観光地に建設され文9，そこでは彼らによって西洋 式のリゾートライフが行われており，リゾートホテルは 日本人がリゾートライフを試行的に体験する場として機 能し，そのことが周辺への西洋式のリゾートライフを楽 しむ拠点としての別荘構築を促進したと思われる。

別荘地は，これらが単独で，あるいは組み合わさって 成立していったといえる。例えば, 葉山は(1)，(2)，軽井 沢は(1)，(3)，箱根は 3 つずてが成立のきっかけである。

\section{5. 別荘所有の社会・風俗的背景}

別荘所有の社会・風俗的背景を各別荘地ごとに考察す ると, (1)賓客接待（伝統的交流, 西洋的社交), (2)避暑 避寒, (3)療養保養 (温泉浴, 海水浴, 気候療法, 日光浴), (4)農場経営の 4 つの大きな社会・風俗的背景の流れが抽 出される（表一1 の左側）。

\section{(1) 賓客接待}

平安貴族の京都山荘，大名の江戸下屋敷といった日本 の伝統的な別荘形式を反映させつつ, 明治に入り富を得 た富裕階級によって継承されたものである。それは，多 くの立地場所が下屋敷を踏襲したものであることなどか らわかる蚆。上流階級としての教養である茶・詩歌な よ゙の会を核にした交流が行われた。また，西洋的な社交 も大きく関与し，西洋型の社交場の必要性を感じた政財 
表一1 別荘の夕イプと社会・風俗的背景の関連，およびタイプ別の特徵

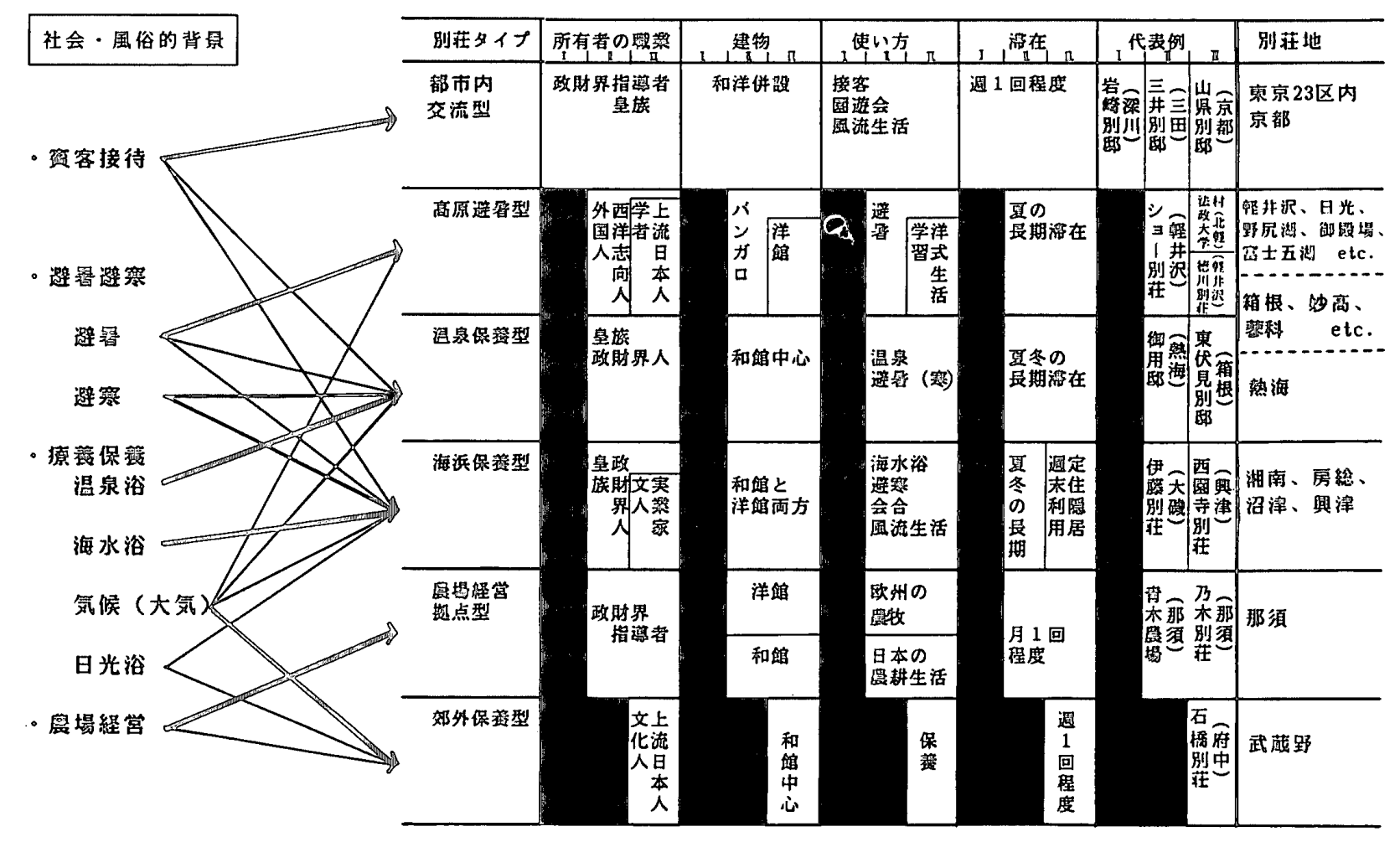

界人が，明治 17 年の鹿鳴館完成以前に構築した，欧米 流の接客, 招宴を行う場でもあった文10),文11。

(2) 避暑避寒

転地して暑さ・寒さを避けるというもので，インドな ごの植民地を経由して西洋人から明治に入って輸入され た社会風俗である。日本の蒸し暑い夏に耐えられなく なった外国人が明治 10 年代に草津・伊香保といった既 存の温泉地に盛んに避暑に行っていたという記 録文121,文131や，日本人が外国人に倣って遠くに避暑に行 くようになったという新聞記事蛙8)などからこのことが 推察される。そのために隅田川なよ゙での納涼船が不人気 になったという記述も当時の風俗誌の文献にみられ文14, わが国の伝統的な避暑法に代わるほど流行したようであ る。

その後, 徐々に日本人の間に広がったが, 第II期にお いては，当時盛んに出版されていた避署案内などに挙げ られている避暑地が既存温泉地や海水浴場がほとんどで あることなどから蛙。次に述べる各種の療養法との組 み合わせで行われていたと思われる。

\section{(3) 療養保養}

これが, 日本人の別荘所有の重要な社会・風俗的背景 となっていた。表一1に挙げられているものは皆,「転 地療法」という西洋医学であるが文15), 温泉浴, 海水浴 は日本古来の湯治の伝統に西洋医学を融合した形で普及 していったものであることが当時の温泉浴，海水浴の入 り方などからわかり，日本人には受け入れやすかったと 推察できる望10)。それに対して，気候療法は全くの輸入
療法であり注11，第 II 期までは主に結核など呼吸器疾患 の治療法で，これにより高原，海浜にサナトリウムが多 く建てられた涪121。日本人に広く意識されはじめたのは， 東京市内の不衛生, 污れがクローズアップされ都市環境 が問題となった第吕期からである ${ }^{\text {世13) }}$ 。これが国木田独 歩『武蔵野』(明治 31 年) に端を発した「武蔵野ブーム」 につながり，気温の違いのないタイプの郊外別荘地を形 成していくことが当時の武蔵野・東京郊外関連の文献な どから読み取れる注14)。この頃になると, 病気の治療や 健康維持のために紫外線を浴びる日光浴という蟟法も盛 んになり始めた望15!。

\section{(4) 農場経営}

2つのパターンがあり,ひとつは西洋式の農場経営主16) である。明治 10 年代に, 政府の殖産興業政策に沿って, 西欧式大農場を試みるために高原の官有地が華族ら民間 に払い下げられ，大規模な開拓が行われ牧場や農場が生 まれた文16)。これら高原開拓地における別荘は，明治 17 年に西欧の貴族制度をもとにした華族令の公布によって 爵位を得た明治の元勲達が貴族としてのステイタスを得 るために，西洋貴族のようなライフスタイルを過ごす捷 点として所有された。もうひとつは，いわゆる「帰農」 の心情から生まれたもので, 晴耕雨読の生活を営みたい という日本人の伝統的な思想である文17!。

\section{6. 立地と使い方からみた別荘のタイプとその特徴}

3,5 での考察を踏まえて, 別荘の立地とその社会・風 俗的背景から夕イプを分類すると6つに分けられ，それ 
ぞれ，a. 都市内交流型，b. 高原避暑型，c. 温泉保養型， d. 海浜保養型，e. 農場経営拠点型，f. 郊外保養型と名 付ける。さらに，ここでは，各別荘地の所有者名簿，ヒ アリングなどから別荘地ごとの代表的な別荘所有者を ピックアップし，彼らの伝記・日記・自伝などを収集・ 分析することにより,「所有者の職業」,「建物の形態」, 「使い方 (別荘での活動内容)」,「滞在の形態」を明らか にする。それをまとめたものが表一1である。

a) 都市内交流型別荘

立地場所は, 現在の東京 23 区内の隅田川, 多摩川の 川ベり，東京湾を望む高台で，これらの多くは江戸時代 の下屋敷跡である。

主に第 I 期に，財界人によって構築され，代表例とし ては, 深川の岩崎家別邸 (明治 11 年), 王子飛鳥川の渋 沢家別邸（同年）なよ゙が挙げられる。このタイプの別荘 には和館と洋館が併設されていたという特徴がある。そ の使い方は，和館の方は，江戸期の大名の別荘ライフを 踏襲して行われた伝統的な芸道である茶, 詩歌なよ゙を嗜 む交流の場として，J・コンドルなどの設計による洋館 の方は，欧米の要人の接待など，欧米型の社交場としてて 使われ盛んに園遊会が開かれていた文181。

また，関東圏ではないが, 京都にも東山山麓を中心に， 住友，野村といった関西の財界人に加えて，東京に本宅 を置く政財界人の別荘も構えられた。代表例としては山 県有朋の無隣庵がある。これらは明治以前からの京都の 伝統的な別荘の系譜を継承しており，文化的な行事を核 に，交流，接待，会合などに使われた。

b) 高原避暑型別荘

高原避暑型別荘が現れ始めた第 II期には，別荘所有者 は，在日外国人が中心で新渡戸稲造など一部の西洋志向 の強い人がいたに過ぎなかった。軽井沢における明治 44 年の日本人の別荘は 40 戸であったが，外国人の別荘 は135 戸に及んでいた文191。林期になると 3 で述べたよ うに日本人の上流階級が高原に押し寄せ, 軽井沢に朝香 宮, 竹田宮文201, 大隅重信, 徳川慶久文21!, 箱根に閑院宮, 東伏見宮文8)，妙高の久邇宮，三井高公文22)などといった 宮家や政財界の指導者も多く別荘を構えるようになっ た。建物に関しては, 外国人別荘は, 軽井沢の「バンガ ロー」文23)，野尻湖の「キャビン」文24) のような簡易な建 物であった。一方, 日本人別荘は, 練川家, 徳川家の別 荘など第囵期の軽井沢で人気を博した「あめりか屋」に 代表される洋風建築が多かった文231。

その使い方は, 当初は, 避暑を主目的にしながらもこ のような西洋式生活の模倣の舞台であり, テニス, ゴル フといった西洋から輸入されたばかりのスポーツ, 外国 人との各種パーティなど西洋式生活が積極的に行われて いた文25!。第 III 期に入ってもこの傾向は続き，軽井沢以 外の別荘地でも当時のハイカラな流行として西洋式り
ゾートライフが展開されたことが，別荘所有者へのヒア リング，当時の写真などから明らかにされた。

例えば，大正初期の『赤倉温泉図絵」という墨絵には， 「ハイカラな紳士達がテニスに興じ, 乗馬に励み, 玉突 きに凝り，サイクリングをする」様子が描かれている。

これとは違うパターンとして北軽井沢の「法政大学 村」(女) ・ 木崎湖の「学者村」文26) といった別荘所有者の中 心が学者で夏季大学も併設された学習・研究を主なる活 動と銘打った別荘地が登場したことは注目される。この 頃になると, 軽井沢でも夏季大学が開設された文27。

c）温泉保養型別荘

立地する地域は温泉資源が存在する所で, 箱根, 蓼科 など高原部，熱海など海浜部の温泉地がある。

使い方の特徴は, 高原避暑型の西洋式生活を取り入れ ようというスタイルとは違い，日本古来の伝統である湯 治をしながら豊かな自然を相手に風流に過ごす純日本的 なものであった。ここでは高原避暑型でみられたホテル などでのパーティーを中心とした交流は少なく，別荘内 における在宅接待が中心であったと思われる。軽井沢の ようなコミュニティ施設・組織は存在しなかった。建物 も，木々に囲まれた茅蕞きの和風建築が多かった。現存 する例としては, 箱根宮ノ下の御用邸が挙げられる。滞 在期間は, 湯治のスタイルを受け継ぎ， 2,3 週間の比較 的長いものであった。

d）海浜保養型別荘

別荘所有者は，海浜保養型別荘が現れ始めた第 II 期に は, 皇族, 宮家, 政財界人の要人など特権階級に属する 日本人全般にわたっていたが，高原避暑型に比べると外 国人の割合は小さかった。前述の外務省記録によると明 治 25 年に外国人は軽井沢に 22 人が別荘を所有していた のに対して鎌倉では6人に過ぎなかったことがわかる。

それに対して，日本人はIII期には高原部よりも海浜部 に別荘を構えるものが多く, 例えば, 高原避暑型別荘を 先駆的に所有した日本人として, 桂太郎, 岩崎弥之助が いるが，桂は明治 32 年には葉山に既に別荘を所有して いたが軽井沢に所有したのは約 10 年後の 43 年であ り文28)，同様に岩崎も 23 年には大磯に既に所有していた

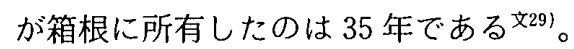

第 II 期から III 期に至る継時的な特徴として, 滞在パ ターンの変化が挙げられる。避暑のための夏期の長期滞 在, 避寒のための冬期の長期滞在という 2 シーズン制の 利用が主流であった状況に，週末ごとに利用するスタイ ルが加わった。さらに定住利用もみられるようになった。 これは, 避寒にも適する温暖な気候と, 湘南など比較的 東京から近距離にある地域が多かったためである。これ は使い方の変化ともかかわっており, 長期滞在の際の主 目的は, 海水浴, 避暑, 避寒であったが（当時の療法と しての海水浴は $2 \sim 3$ 週間にわたって行わないと効能が 
表一2 原 敬の別荘利用日数と泊数

\begin{tabular}{|c|c|c|c|}
\hline \multicolumn{2}{|c|}{ 総利用日数：123日 } & \multicolumn{2}{|c|}{ 泊数： 82 泊 } \\
\hline 1 泊 2 旦 & 2 泊 3 日 & 3泊 4日 & 4 泊 5日 \\
\hline 7 回 & 30 回 & 2 回 & 1 回 \\
\hline
\end{tabular}

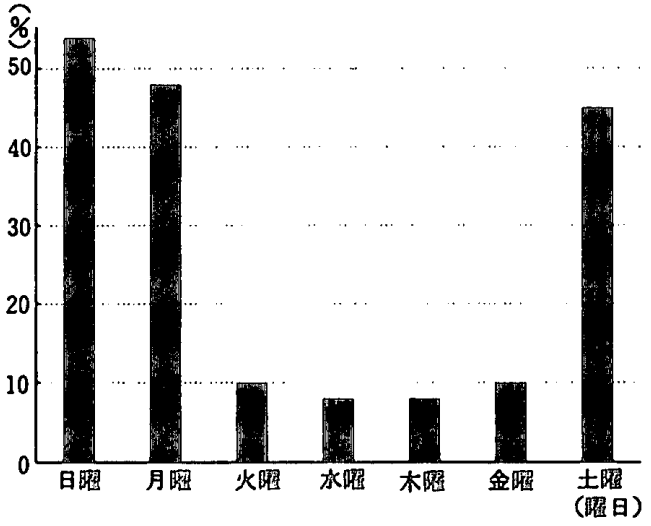

図一4 原 敬の曜日別別荘滞在率

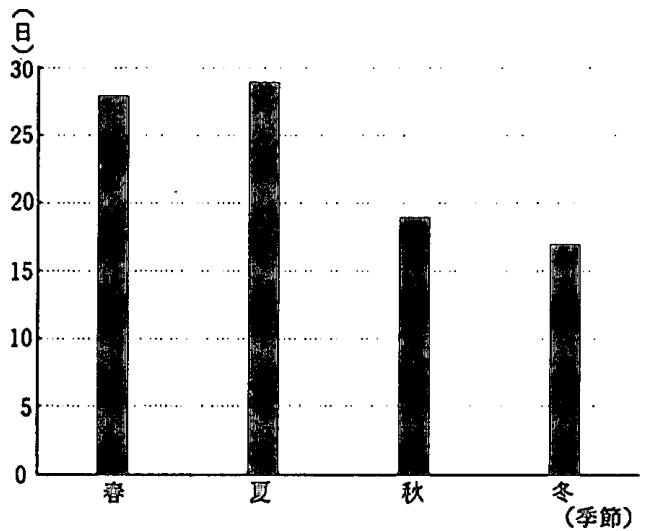

図一5 原 敬の季節別滞在日数（季節別滞在日数は大正 9 年 7 月〜同 10 年 6 月をカウント)

ないとされていた), 週末利用の際の目的は, 保養を目 的としたものに会合や接客が加わるようになった。例え ば, 週末ごとに腰越（鎌倉）の別荘を訪れていた原 敬文301, 大磯で政治の行方を決める重要な会議を度々開 いていた伊藤博文站1 がいる。原 敬の別荘利用状況を 「原敬日記」より分析してみると，原敬は土曜日の夕 方に仕事を終え腰越に行き, 2 泊して月曜の朝に東京に 帰るというパターンがほとんどであった。その別荘は週 末の休養または賓客接待に当てられ, 気候のよい 4 月 7 月はほとんどの週末に利用されていたことがわかる。

また, 定住した例としては, 隠居の地として選ぶ場合 が多く, 大磯に本籍を移した伊藤博文の「滄浪閣」, 古 希を迎え小田原に山県有朋が構えた「古希庵」文22), 西園 寺公望が晚年には一年の四分の三を過ごした興津(静岡) の「坐漁荘」文33) が挙げられる。

e）農場経営拠点型別荘

農場経営の社会・風俗的背景の 2 つのパターンに従っ $\tau$, 西洋式農場経営の拠点型 (e-1) と, 日本式農耕生 活の拠点型（e-2）の大きく2つのタイプに分かれる。 建物に関しては，e-1 型は地方に設けた農場とそれに付 帯する洋館，e-2 型は農家風の和館が多かった。代表例 としては，e-1型には那須に広がる山県有朋，松方正義， 青木周蔵, 西郷従道, 大山䇴ら, 軽井沢の雨宮敬次郎, 岩手の岩崎家 (現, 小岩井農場) の農場があり, e-2 型 には那須の乃木将軍, 東京府中の東郷元帥の農場がある。 これらの使い方の主目的は避暑ではなく農場経営である と思われる。このことはこれらの立地場所から推察され る。e-1 型が多く立地する那須では農場別荘群は代表的 な高原避暑型別荘の一つである那須御用邸に比べると避 暑に最適とはいえない標高の低い所に立地していること (那須御用邸：標高 $700 \mathrm{~m}$ に対して, 山県邸：標高 380 $\mathrm{m}$, 松方邸：330 m, 青木邸 $400 \mathrm{~m})$ ，また, e-2型は気 候の変化がない府中を中心にした東京郊外にも多く立地 していることである。別荘所有者は, e-1 型は明治維新 の功労者である新華族, e-2 型は軍人が多い点に特徴が ある。滞在パターンは，e-1 型では夏期を中心に年に数 回訪れるのが基本的であるが部，文34)，乃木は休職なよ゙ の時は那須に長期滞在して, 質素な農耕生活を行ったと その伝記には記されている文35)。

\section{f）郊外保養型別荘}

IIII期になって表れる別荘のタイプで，最大の特徴は， 保養を主目的としながらも気温の変化を求める避暑避寒 が関与しない点である。立地場所は独歩が『武蔵野』の 中で記した武蔵野の範囲内にある文36)。建物は和館がほ とんどであったが，武蔵野のなかでもどのような場所が 選ばれていたかというと，多摩川沿いの富士山がよく見 える地に多く立地していた。独歩の『武蔵野』はそれま での日本人の風景観を大きく変えたといわれているが, 別荘の立地がその風景観とよく一致していることは,「ま た多摩川は，ビうしても武蔵野の範囲に入れなければな らぬ。」や「…殊に富士で分明る。富士を高く見せてあ だかも我々が逗子の“あぶずり”で眺めむるように見せ るのはこの辺に限る。」などの記述からもわかる。

滞在パターンは主に日帰りでしばしば利用されてお り，その使い方としては，ゴルフ，釣り，亿モ掘りなど の自然の中で遊ぶレクリエーションが行われていたこと が別荘の元所有者へのヒアリングなどからわかった妾17)。 現存する例としては，松方家の玉川別邸，石橋正二郎の 府中鳩林荘がある。

\section{7. 結 論}

本論文で明らかにした結論は以下の 3 点である。

（1）戦前の関東圈における別荘地の成立と展開は，そ の分布などから，

I 期…江戸期の下屋敷スタイルの継承期で，都市内に 立地していた。

II 期…西洋の社会風俗の導入期で，気候風土の異なる 
地域への立地が始まり，海浜部を中心に展開し ていた。

III 期…所有者層の拡大と避暑の浸透期で，高原を中心 に展開していた。

の三期に分けられる。また, 別荘地形成のきっかけとし て，(1)外国人による別荘構築，(2)皇族による別荘構築，

(3)リゾートホテルの開業，の3つがあった。

（2）別荘を所有するにあたっての社会・風俗的背景に は, 日本古来の「賓客接待」, 西洋から輸入された「避暑 · 避寒」,「大気療法」, 日本古来のものと西洋から輸入さ れたものの融合である「温泉浴」,「海水浴」,「農場経営」 があった。なかでも療養・保養が, 日本人による別荘地 の成立と展開には大きな影響を与えていた。

（3），戦前に存在した別荘のタイプには，立地と使い方 を中心に分類すると, 「都市内交流型」,「高原避暑型」, 「温泉保養型」,「海浜保養型」,「農場経営拠点型」,「郊 外保養型」の6つが存在した。

\section{本論文に関連のある既発表論文}

a) 十代田朗ほか 2 名：明治・大正期における湘南および房 総地域の臨海部別荘地の成立過程, 日本都市計画学会学 術研究論文集, 第 20 号, pp. 331 336, 昭和 60 年

b）安島博幸ほか 2 名：明治期の別荘の立地と様式に関する 研究, 日本観光研究者連合研究発表論文集, No. 1, pp. $53 \sim 58$, 昭和 61 年

c) 西村 真任か2 名：かが国近代高原リゾートの成立と展 開, 日本都市計画学会学術研究論文集, 第 22 号, pp. 61 一6, 昭和 62 年

d）武井裕之ほか 3 名：戦前の東京における別荘・別邸の立 地とその成立背景に関する研究，日本建築学会学術講演 梗概集 F, pp. 319 320, 昭和 62 年

e) 西澤倫太郎ほか 3 名：野尻湖における外国人別荘地「神 山国際村」の成立亡展開, 観光研究, Vol. 3/No.1 · 2 合 併号, pp. 1 8, 平成 2 年

f）勝又宏幸ほか 1 名：戦前の御殿場における高原りゾート の成立と展開, 日本都市計画学会学術研究論文集, 第 25 号, pp. 319-324, 平成 2 年

注

1）論文 a), c), d), e), f) がある。

2)「東京建築探偵団：近代建築ガイドブック [関東編，鹿島 出版界, 昭和 57 年」, 「突戸 實：軽井沢別荘史, 住まい の図書出版局, 昭和 62 年」などがある。

3）例えば, 葉山では, 明治年代には, 皇族 3 人, 政治家 9 人, 実業家 1 人, 学者 4 人, 軍人 2 人 (文献了)による)であっ たが, 昭和 2 年には, 皇族 4 人, 政治家 5 人, 実業家 55 人, 学者 23 人, 軍人 1 人（文献价による）上所有者層が変 化している。

4）田代達雄氏 (赤倉温泉郷土史家) へのヒアリングより。

5) 大正 9 年 7 月 26 日の「朝日新聞』に「高原の避署地とし て軽井沢が，近年ますます俗化するため，信州の富士見 が都会人に認められてきた」と記されている。

6) 論文 e),f) に詳しい。
7）例えば，岩崎家の別邸「清澄園」は松平家などの，「六義 園」は柳澤吉保の下屋敷跡である。

8）例えば, 東京朝日新聞：明治 25 年 8 月 20 日付には,「外 国人を見習って避暑旅行を始めるようになり，今日では， 避暑をしなくては紳士ではないかのように思われるよう になった」というようなことが記されている。

9)「読売新聞：明治 26 年 7 月 5 日付掲載の「避暑地案内」」, 「風俗画報 368 号 (明治 40 年 7 月) の「避暑地案内】」,「日 本新聞社による明治 41 年 7 月 16 日付の「日本一避暑地 投票」」な゙にこの傾向がみられる。

10）諭文 a)に詳しい。

11）文献 15）にも「古来本邦に於て特に之を唱道するものあ らざりし……上記されている。

12）高原では明治 10 年の箱根 (文献ウ)), 海浜では同 19 年 の鎌倉（文献五))をはじめとして次々と建てられた。

13）文献才）によると，大正後期には，新中間層の母親に「空 気をやかましく云ふ」習慣が成立するなど，都市環境へ の関心の高まりから“オゾン”という言葉が広まった。

14）武蔵野関連の文献としては, 「並木仙太郎：武蔵野, 民友 社, 大正 2 年」,「田村剛編：武蔵野, 科學主義工業社, 昭和 16 年」, 「大岡昇平：武蔵野夫人, 新潮社, 昭和 28 年」 などがある。東京郊外に別荘を構えることを蔦的る文献 としては，保谷・石神井などを理想的新別荘地として投 票で選定した「中柄正一：郊外住宅と新別荘地, 至誠堂, 大正 5 年」があるが, 国立, 桜新町といった郊外住宅地 分譲の売り出し広告にも別荘地としても適しているとい う記述がみられる。

15）日光浴に関する啓蒙書として,「文明協会：日光と健康, 昭和 4 年」, 「正木俊二：綜合日光療法, 三光書院, 昭和 5 年」,「三戸時雄: 日光浴と空気浴, 診断と治療社, 昭 和 5 年」などが次々と出版された。

16）米国製大型農業機械を導入した数百へクタール単位の大 規模経営や，羊や乳牛の飼育による羊毛や乳製品の製造 を行う。

17）森村登代子氏など。

\section{参考文献}

1）大橋左狂：現在の鎌倉, pp. 44 45, 明治 45 年

2）島崎 清：軽井沢百年の歩み, p. 40, 昭和 53 年

3）信濃町編：信濃町誌, pp. 1116 1120, 昭和 43 年

4) 北軽井沢大学村組合：大学村五十年誌, pp. 13 20, 昭 和 55 年

5）外務省記録：外国人ニシテ日本人名義フ以ッテ土地又八 家屋ヨ所有スルモノノ調查, 明治 25 年

6) Tourist's guide and interpreter, 1891

7) Ernest Mason Satow C.M.G., Lieutenaut A.G.S. Hawes: A handbook for travellers in central and northern Japan, 1884

8）井原頼明：增補皇室辞典, 冨山房, pp. 139 141, 昭和 17 年

9）村岡 實：日本のホテル小史，中央公論社， p. 79， p. 99， p. 134 , 昭和 56 年

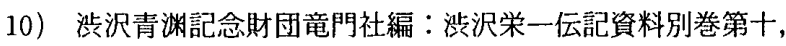
p. 266 , 昭和 46 年

11) 岩崎家傅記刊行会編: 岩崎久弥傅, 東京大学出版会, pp. 290 292, 昭和 32 年 
12）萩原 進：草津温泉史, 文進社, p. 60 , 昭和 23 年

13）伊香保町教育委員会編：伊香保誌，伊香保町役場，p.137, 昭和 45 年

14）平出鉃二郎：東京風俗誌一中の巻一畐山房, p. 47, 明治 34 年

15）長尾折三：日本轉地療養誌，吐㮩堂書店，pp. 1 2, 明 治 43 年

16）磯 忍：那須野ヶ原開拓のあらまし（改訂版），pp. 14〜 16 , 昭和 50 年

17）藤森照信：那須野ケ原プランテーション別荘群, NIKKEI ARCHITECTURE 1 月 27 日号, pp. 128 135, 昭 和 61 年

18）平出鏗二郎：東京風俗誌一下の巻一富山房, pp. 110 112 , 明治 34 年

19）文献 2), p. 39

20）朝吹登水子編：わが心の軽井沢，軽井沢を語る会，p. 35 , 昭和 61 年

21）文献 2), P.44

22）渡辺慶一：赤倉温泉沿革史，赤倉温泉組合，p. 87，昭和 30 年

23）宾戸實：洋風別荘地帯, SPACE MODULATOR, No. 60 , 日本板硝子 KK, pp. $16 \sim 23$, 昭和 57 年

24）論文 e), p. 6

25）朝吹登水子：私の軽井沢物語, 文化出版局, 昭和 60 年

26）大町市史編箖委員会編：大町市史, 第五巻, pp. 856 857, 昭和 59 年

27）文献 2), p. 48
28）徳富猪一郎：公爵桂太郎傅, 故桂公爵記念事業会, pp. 979 987, 大正 6 年

29）岩崎家傅記刊行会編：岩崎弥之助傅, 東京大学出版会, pp. $451 \sim 461$, 昭和 32 年

30）原奎一郎編：原敬日記第 9 巻首相時代篇下, 乾元社, 昭 和 25 年

31）朝日新聞横浜支局編：残照神奈川の近代建築，p. 80 , 昭 和 57 年

32）徳富猪一郎：公爵山県有朋傅, 山県有朋公記念事業会, p. 1138 , 昭和 8 年

33）安藤徳器: 許庵公影譜, 審美書院, 'p. 101, 昭和 12 年

34）徳富猪一郎：公爵松方正義傅, 公爵松方正義傅記編策会, pp. 1165 1176, 昭和 10 年

35）日本歴史学会編：乃林希典, 吉川弘文館, 昭和 35 年

36）国木田独歩：武蔵野, 新潮社, pp. 24 26, 昭和 24 年

ア）郷土誌編委員会編：葉山町郷土誌, pp. 94 95, 昭和 50 年

1) 葉山小学校編：葉山郷土誌, p. 42, 昭和 5 年

ウ）箱根町教育委員会: 箱根近代百年史年表, 箱根町, 昭和 43 年

工）鎌倉市市民相談部広報課：愛されて 100 年 鎌倉海水浴 場, 鎌會市役所, p. 6 , 昭和 59 年

才）原田勝正：汽車・先車の社会史, 講談社, pp. 173 174, 昭和 58 年

(1991 年 7 月 31 日原稿受理, 1992 年 4 月 8 日採用決定) 